\author{
Annual Report \\ Grant DE-FG02-87ER45293 \\ August 1, 1991 to July 31, 1992

\section{EFFECT OF ALLOYING ELEMENTS ON PASSIVITY AND BREAKDOWN OF PASSIVITY OF Fe- AND Ni-BASED ALLOYS. MECHANISTICS ASPECTS}

\author{
Submitted to \\ U.S. Department of Energy \\ Office of Basic Energy Science \\ Washington, DC 20585 \\ By \\ Z. Szklarska-Amialowska \\ Department of Materials Science and Engineering \\ The Ohio State University \\ Columbus, Ohio 43210
}

June, 1992 


\section{TABLE OF CONTENTS}

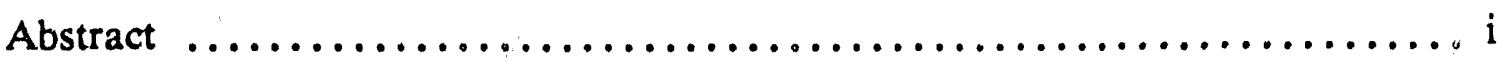





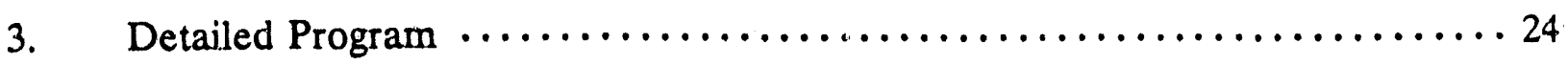

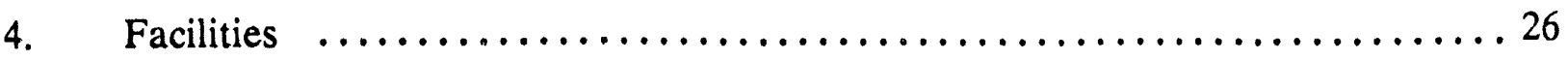

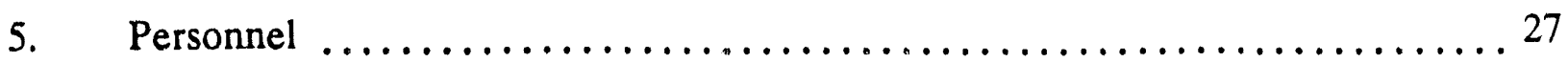

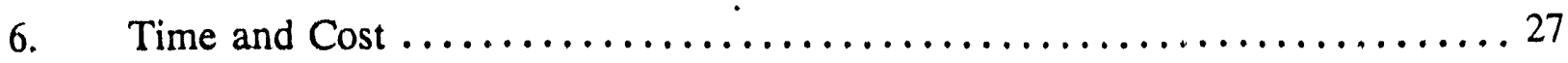

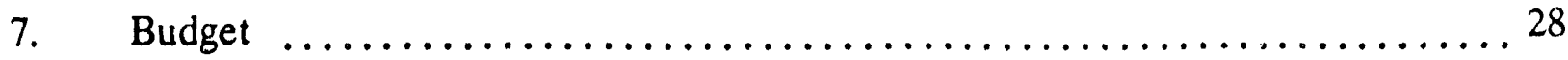

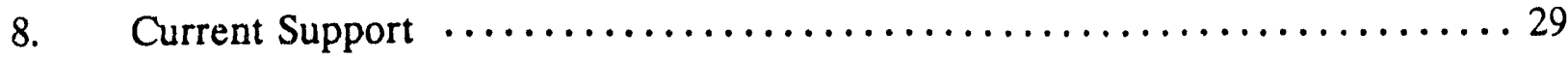

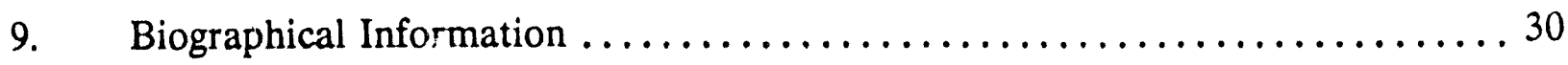

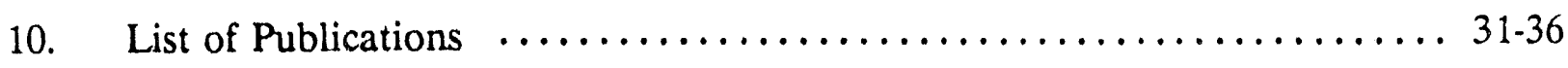

Appendix - Text of related papers to the proposal published by the author

1) Structure, Composition, and Pitting Behavior of sputtered Al, Al-Cr and Al-Ta

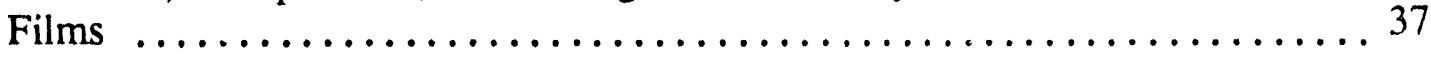

2) Optical and Impedance Characteristics of Passive Films on Pure Aluminum .55

\section{DISCLAIMER}

This report was prepared as an account of work sponsored by an agency of the United States Government. Neither the United States Government nor any agency thereof, nor any of their employees, makes any warranty, express or implied, or assumes any legal liability or responsibility for the accuracy, completeness, or usefulness of any information, apparatus, product, or process disclosed, or represents that its use would not infringe privately owned rights. Reference herein to any specific commercial product, process, or service by trade name, trademark, manufacturer, or otherwise does not necessarily constitute or imply its endorsement, recommendation, or favoring by the United States Government or any agency thereof. The views and opinions of authors expressed herein do not necessarily state or reflect those of the United States Government or any ager:y tiereof. 


\begin{abstract}
On the basis of the literature data and the current results, the mechanism of pitting corrosion of $\mathrm{Al}$-alloys is proposed. An assumption is made that the transport of $\mathrm{Cl}$ - ions through defects in the passive film of aluminum an aluminum alloys is not a rate determining step in pitting. The pit development is controlled by the solubility of the oxidized alloying elements in acid solutions. A very good correlation was found between the pitting potential and the oxidized alloying elements for metastable $\mathrm{AL}-\mathrm{Cr}, \mathrm{Al}-\mathrm{Zr}, \mathrm{Al}$ $\mathrm{W}$, and $\mathrm{Al}-\mathrm{Zn}$ alloys.

We expect that the effect of oxidized alloying elements in other passive alloys will be the same as in Al-alloys. To verify this hypothesis, susceptibility to pitting in the function of alloying elements in the binary alloys and the composition of the oxide film has to be measured. We propose studying $\mathrm{Fe}$ - and Ni-alloys produced by a sputtering deposition method. (Using this method one-phaseous alloy can be obtained, even when the two metals are immiscible using conventional methods. Another advantage to studying sputtered alloys is to find new materials with superior resistance to localized corrosion.
\end{abstract}




\section{INTRODUCTION}

The research performed on metastable aluminum alloys clearly indicates that the pitting potential of alloys is a function of the solubility of the oxides (hydroxides) of the alloying elements in acid solutions. The lower the solubility of the oxide of the alloying elements in acid solution, the higher the pitting potential of the alloy. The higher pitting potential of alloys containing $\mathrm{Cr}$ is often explained by the better properties of an oxide (hydroxide) film containing chromium oxide. However, the measurements of $\mathrm{Cr}$ in the passive film on $\mathrm{Al}-\mathrm{Cr}$ alloys indicate that the chromium oxide content increases with the potential. Hence, at higher potentials, the film would be expected to be more protective than at less positive potentials. This is inconsistent with the observation that pitting occurs easier at higher potentials.

The most positive pitting potential of all the studied Al-alloys was obtained on the Al-W alloy, but $\mathrm{W}$ was not found in the oxide film. Mo is also absent in the oxide film formed on stainless steel and it is well known that an alloying stainless steei with Mo increases resistance to pitting.

These results contradict or weaken the hypothesis that alloying elements influence the susceptibility to pitting by altering the properties of the oxide films.

Obviously, the composition and structure of oxide films on alloys can change as a result of slow selective dissolution within the passive region of the potentials and perhaps as a result of different mobility of the cations. This process occurs faster at higher potentials and in the presence of more aggressive bulk solutions. 
Chromium enrichment in the passive film on Al-Cr alloys is due to a much slower solubility of chromium oxide than aluminum oxide at a neutral $\mathrm{pH}$. In contrast to the chromium oxide, the solubility of $\mathrm{WO}_{3}$ is higher than that of the alumir um oxide at neutral $\mathrm{pH}$ 's, hence no enrichment of $\mathrm{W}$ is observed in the oxide film of the ailoy. Hence, the composition of the passive films on the alloys is a result of their selective dissolution characteristics in a given solution.

We are convinced that the effect of alloying elements on the pitting corrosion of other systems, i.e. on iron and nickel-based alloys is also related to the solubility of the oxide (hydroxides) of the alloying elements and the oxide of the parent metal in : .id solutions. The specific role of $\mathrm{Cl}$ - ion arises form its small size that allows easy penetration of the oxide film through defects in the oxide film.

We propose to verify the above hypothesis by performing measurements of the susceptibility to pitting of the Fe- and Ni-based alloys and correlate the obtained results with the solubility and composition of the passive films.

\section{BACKGROUND}

It is widely accepted that the resistance of metals to pitting corrosion is determined by the physical, electrical, and mechanical properties of the passive film. Therefore, several experiments have been performed to find the composition of oxide film on specific alloy systems that give the best results. The high resistance of stainless steel to pitting, for instance, is explained by the presence of chromium oxide on the metal surface (1). A large number of investigators have attempted to rationalize the favorable effect of Mo in stainless steel on pitting. No enrichment of Mo in the passive film has been reported in the majority 
of papers written about these studies (1). Different hypotheses have been proposed to explain these observations, but are not yet satisfactory. Despite a large number of studies on the influence of alloying elements on pitting, the mechanistic influence of alloying elements on localized corrosion remains unclear.

It seems that recent experiments performed on different metastable Al-X alloys (where $\mathrm{X}$ is $\mathrm{Cr}, \mathrm{Ta}, \mathrm{Mo}, \mathrm{W}, \mathrm{Zr}$ ) (2-9) are very valuable in gaining a better understanding of not only the effect of alloying elements but the mechanism of pitting corrosion as well. It was found that all of the above alloying elements, present in soid solution, significantly improve the resistance to pitting corrosion.

Using XPS to determine the composition of the film formed in a $\mathrm{NaCl}$ solution, it was reported that in the case of $\mathrm{Al}-\mathrm{Mo}, \mathrm{Al}-\mathrm{Cr}, \mathrm{Al}-\mathrm{Zr}, \mathrm{Al}-\mathrm{Ta}$ alloys the passive films contain $5-10 \%$ (at) of oxidizing solute $(3,4)$. It was also found that the concentration of the oxidized solute in the passive film depended strongly on the overpotential, increasing by a factor of approximately five from $\mathrm{Ec}$ (open circuit potential) to $E_{n p}$ (pitting potential) (7). However, in the case of the Al-W alloy, only at very high anodic potentials was a small quantity of $\mathrm{WO}_{3}$ found on the surface film (7). The oxide film was reported to be very thin on Al-W (7), and $\mathrm{Al}-\mathrm{Ta}$ (11), and thick on Al- $\mathrm{Zr}$ (3) and Al-Mo (4) alloys. According to the researchers, the thicker film on $\mathrm{Al}-\mathrm{Zr}$ is less effective in blocking the transport of chloride and oxygen to the $\mathrm{Al}$ surface.

The authors of these works (5-7) do not offer a single explanation to account for the beneficial effect of all of the above alloying elements. For $\mathrm{Al}-\mathrm{Mo}, \mathrm{Al}-\mathrm{Cr}$, and $\mathrm{Al}-\mathrm{Ta}$ alloys it was proposed that enhanced passivity is achieved by the oxidized solute $\left(\mathrm{MoO}_{4}{ }^{2-} \mathrm{CrOOH}\right.$, or $\mathrm{Ta}_{2} \mathrm{O}_{5}$ ) which made the passive film more resistant to chloride attack due to an 
electrostatic repulsion or a modification of the oxide structure. However, improved properties of Al-W alloys were interpreted as due to a synergetic interaction between $\mathrm{W}$ and hydrated $\mathrm{Al}_{2} \mathrm{O}_{3}$, resulting in the formation of a more stable oxide layer at the metal-oxide interface or enhanced bonding at the metal interface. In summary, all of the above rationalization is connected with the formation of a more protective passive film on the metal surface. Therefore, the rate determining step for the localized corrosion process is ionic diffusion through the passive film.

On the other hand, Natishan et ai. (10) assume that the rate determining step in pitting is adsorption of $\mathrm{Cl}$ - ions on the alloy surface. They showed that a correlation exists between the pitting potential of several metals in $1 \mathrm{~N} \mathrm{NaCl}$ solution and the $\mathrm{pH}_{2 \mathrm{ch}}(\mathrm{pH}$ of zero charge) of hydrated oxides of these metals $\left(\mathrm{Ta}, \mathrm{Ti}, \mathrm{Zr}, \mathrm{Cu}, \mathrm{Fe}, \mathrm{Al}, \mathrm{Zn}, \mathrm{Mg}\right.$ ). $\mathrm{E}_{\mathrm{np}}$ increases with decreasing $\mathrm{pH}_{2 \mathrm{ch}}$. From these results it follows that pitting can occur when the oxide film covering the metal surface is positively charged, allowing $\mathrm{Cl}$ - to be adsorbed. The increase in the pitting potential of ion-inplanted Al-alloys has been attributed to the low $\mathrm{pH}_{\mathrm{zch}}$ of the oxides of alloying elements.

Upon examination of the polarization curves (Fig. 1) it is clear that passive current derisity is almost identical for all supersaturated Al-alloys. It is also interesting to note that the similarity in the passive current extends over the potential range where the passive film is shown to change in composition. Therefore, it is logical to conclude that the physical and/or electrical properties of the alloy passive films are such that they are electrochemically identical (at least during the time of the measurement of the polarization curve) to the passive film on pure Al. It is likely that the defect nature and the tolerance 


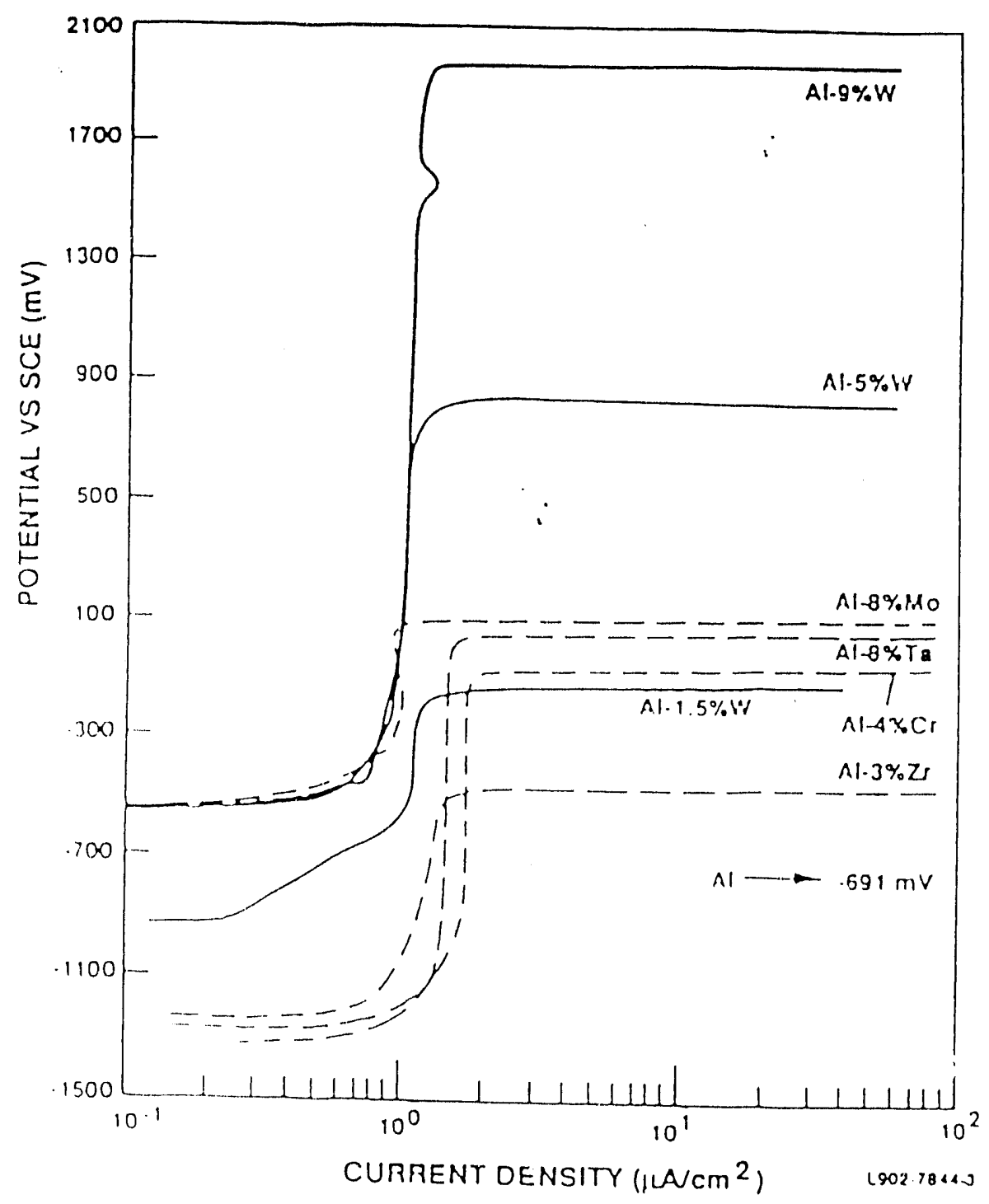

Figure 1: $\quad$ Polarization curves for elemental $\mathrm{Al}$ and several supersaturated $\mathrm{Al}$ alloys in aerated $0.1 \mathrm{~N} \mathrm{KCl}$. (7) 
of the passive film on the alloys for chloride ion transport is about the same as that for a pure Al surface film. As a consequence, the rate determining step may not be associated either with the bulk characteristics of the passive film or with adsorption of $\mathrm{Cl}$ - on the oxide film.

It is well established that pits can develop in chloride solutions only when acidic conditions are established within pits. Therefore, it is obvious that pit growth can proceed only when the oxide film formed on the metal surface is soluble in the acidic pit electrolyte but is only scarcely soluble in the bulk solution. It is interesting to note the correlation between the solubility of the oxidized species of the alloying element in aluminum at acidic $\mathrm{pH}$, and the pitting potential. Figures 2 and 3 are a compilation of the results of $\mathrm{E}_{\mathrm{np}}$ of aluminum alloys with various alloying elements in $\mathrm{NaCl}$ solution, obtained by differe at authors as a function of the solubility of the oxide of the alloying elements at $\mathrm{pH} 7$ and 0 . (The data taken for plotting the curves in all figures given in this paper are collected in Table 1). The lower the solubility of the oxidized species, the higher the pitting potential. This is clearly due to a much higher driving force (anodic potential) necessary to produce a low enough $\mathrm{pH}$ in the occluded cell to cause dissolution of the oxide film. For example, in super-saturated $\mathrm{Al}-\mathrm{Cr}$ alloys, although pits may nucleate at potentials not much higher than the pitting potential of pure aluminum, they would be metastable and stop growin because $\mathrm{CrOOH}$ or $\mathrm{Cr}_{2} \mathrm{O}_{3}$ is stable inside the pit and would prevent further dissolution. Upon increasing the applied potential the $\mathrm{Al}$ dissolution rate increases and the local cell $\mathrm{pH}$ continuously decreases by hydrolysis, and eventually drops to the level where $\mathrm{CrOOH}$ is soluble, thereby giving rise to pitting. As seen in Fig. 2, the results of $E_{n p}$ vs solubility for 


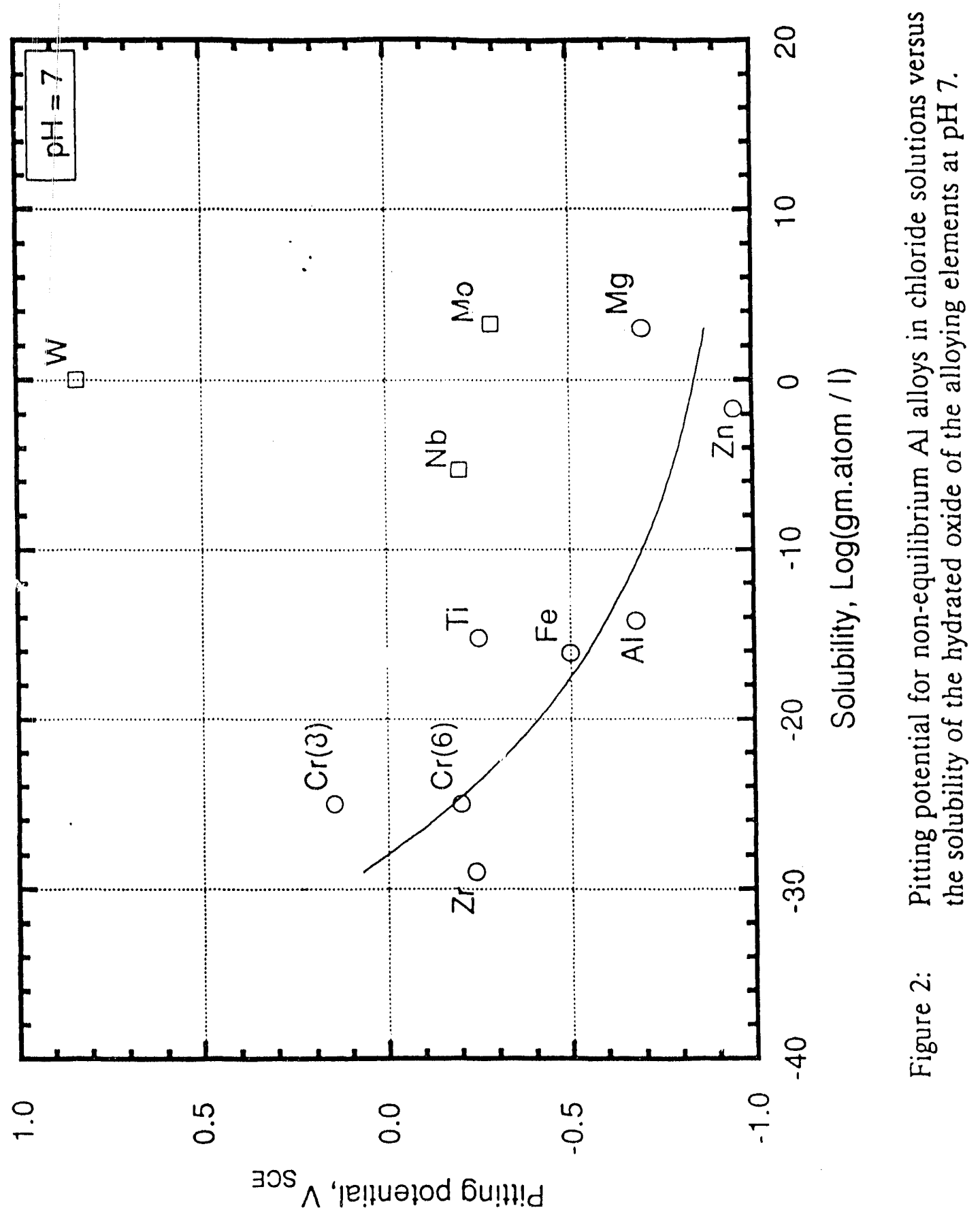




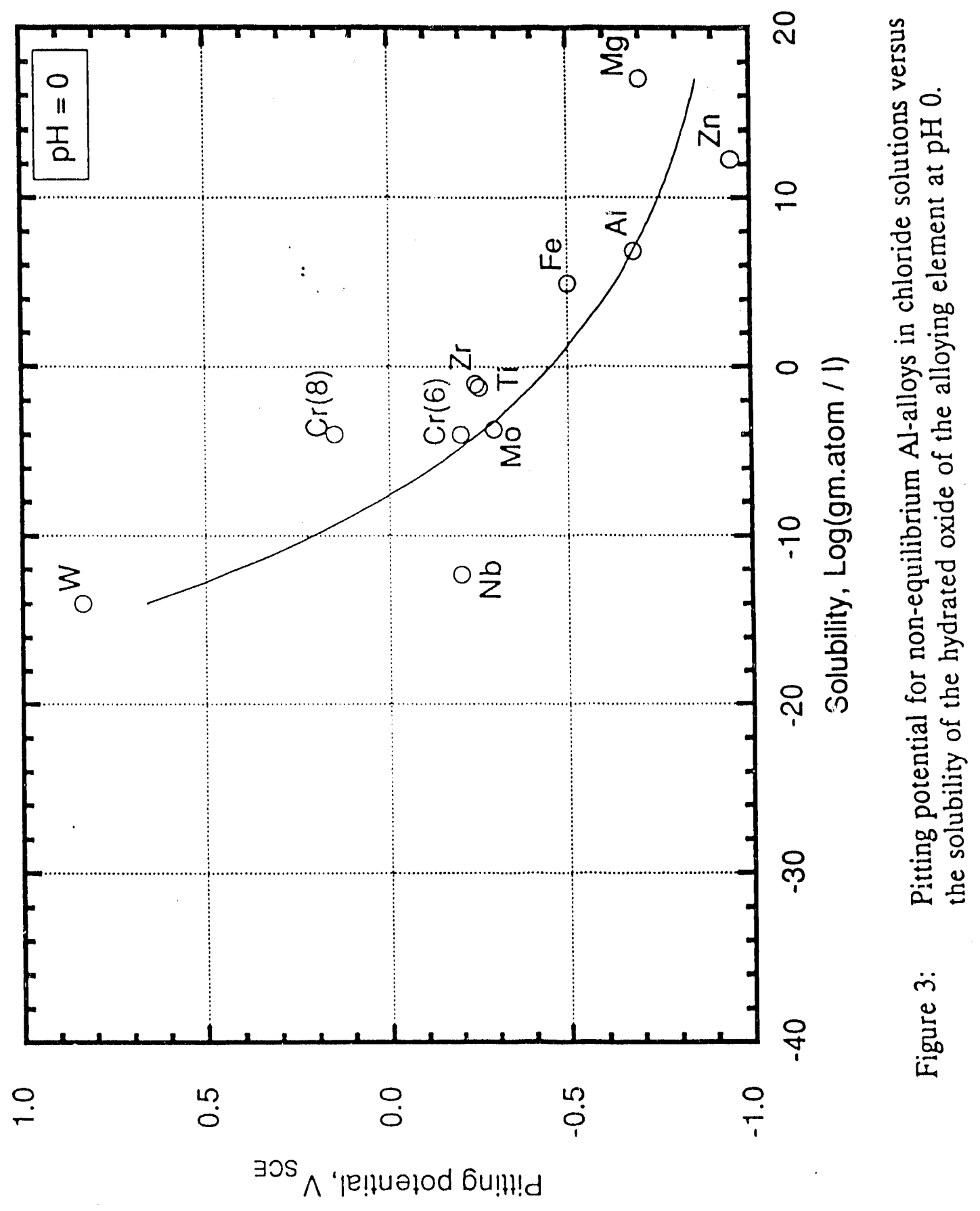




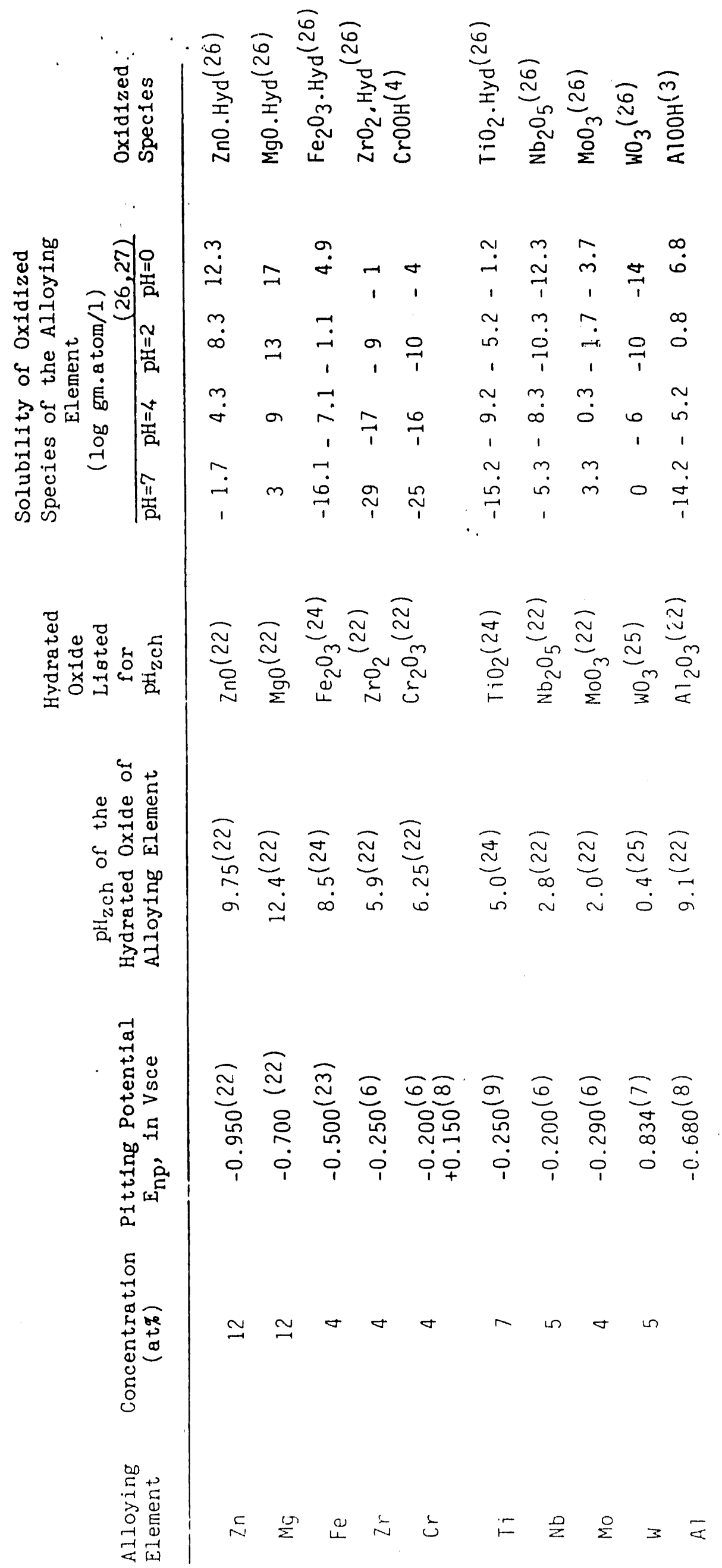


alloys containing Mo and W deviate significantly from the correlation obtained for other alloys. However, it should be noted that the solubility of Mo and W oxides are higher at $\mathrm{pH} 7$ than at $\mathrm{pH}$. Therefore, even at high anodic potentials as the $\mathrm{pH}$ in the occluded cell decreases, the oxides of these alloying elements remain stable resulting in a superior pitting resistance.

The hypothesis that physical, electrical, and mechanical properties of the passive film on the various non-eciuilihrium alloys and on pure aluminum are similar initiclly and the passive film possesses many defects which leads to the supposition that pit nucleation occurs as a result of metal dissolution at the metal/oxide interface. This latter suggestion has heen shown to be the case in pure aluminum from studies of the electrochemical noise bohavior (11). Also, the establishment of a critical $\mathrm{pH}$ for pitting which is specified for each alloy system, and which varies with the equilibrium solubility of the relevant surface film in acidic solutions, is the factor that stabilizes pit growth.

The time necessary for the attainment of a critical $\mathrm{pH}$ is seen as the induction time. Although a critical pH is necessary for stable pit growth, it is clear that unstable pit nucleation, repassivation, and hydrogen evolution reactions are continuously taking place during the pit induction period in aluminum.

Assuming that local changes in the concentration of different species within the pit arises due to transport limited processes, a quantitative prediction of such changes can be calculated by employing diffusion equations. According to Galvele (12), the minimum local current density for pit stability in a specific system is dependent on the dimensions of the defect in the metal surface that can serve as a pit nucleus. The product of this minimum 
local current density (i) and a characteristic defect dimension $(x)$ has been shown to cause the local $\mathrm{pH}$ within the occluded cell to attain the critical value that dissolves the passive film. The pitting potential is then the value at which defect chemistry becomes able to sustain a stable active dissolution. The smaller the diffusion path caused by the defect, the greater the pit current density required to cause stable pit growth for a specific system. The difference between the various alloy systems arises from the different values for the critical $\mathrm{pH}$ which in turn requires different threshold $\mathrm{x}$. i values for stabie pit growth. The lower the critical $\mathrm{pH}$ the higher the critical $\mathrm{x}$. i value. The above model assumes inherent defects in the passive film permitting easy transport of the electrolyte with the aggressive anions to the metal/film interface. Also, the defects in the passive film have been suggested to serve as diffusion paths causing agglomeration of the necessary ions.

It is believed that at least a monolayer of the passive film maintains an epitaxial relationship with the metal and that the defective sites in the passive film are primarily located over the grain boundaries of the underlying metal. The passive film may also contain other defects such as pores, cracks and flaws existing over the underlying dislucations or other defects in the metal surface. It has been shown by Carter, Donald, and Saas (13) that the grain boundary thictness in $\mathrm{Al}_{2} \mathrm{O}_{3}$ is $8.5 \mathrm{~nm}$. The diameters of the cilloride ion and the water molectile are 0.36 (14) and $0.31 \mathrm{~nm}(15)$, respectively. It is therefore conceivable that both chloride ions and water can penetrate through the defective sites of the passive film with relative ease and reach the metal surface. The fact that not only the small species, $\mathrm{H}_{2} \mathrm{O}, \mathrm{Cl}$ - might penetrate aluminum oxide but also $\mathrm{CrO}_{4}{ }^{2 \cdot}, \mathrm{PO}_{4}{ }^{2 \cdot}(16)$, and $\mathrm{MoO}_{4}{ }^{2-}(17)$ can be incorporated in the aluminum oxide indicates that this oxide is quite 
defective. Hence, existence of defects on the metal surface is also a necessary condition for pit nucleation. In agreement with this supposition we expect that the pitting potential should be dependent upon the dimensions of the defect on the metal surface.

The pitting potential of metastable $\mathrm{Al}-\mathrm{Cr}$ and $\mathrm{Al}-\mathrm{Ta}$ alloys reported in (8) are significantly higher for the same concentration of $\mathrm{Cr}$ and $\mathrm{Ta}$ than those obtained in different works (3). This was attributed to the homogeneity and fine crystalline structure. Another proof that $E_{n p}$ depends upon the dimension of the defect are the values of $E_{n p}$, being 300 $\mathrm{mV}$ more positive for sputter-deposited Al film (grain size 40nm) than for conventional Al (grain size $44 \mu \mathrm{m}$ ). The fine grained $\mathrm{Al}$ film can be expected to have a smaller defect size than conventional $\mathrm{Al}(8)$.

It is understandable that pitting can occur only when the conditions existing on the metal surface allow for transport of $\mathrm{Cl}$ - through the oxide film. Hence, the adsorption of $\mathrm{Cl}$ - should not be hampered (for example, by some inhibitors which can adsorb on the metal surface more readily than $\mathrm{Cl}-$-) or by forming insoluble salts. In solutions not containing inhibitors, the transport of $\mathrm{Cl}$ - ions will be dependent upon $\mathrm{Cl}$ - concentration, temperature, potential and the defect size in the oxide film.

As was mentioned before, in the case of studied Al-alloys, the electrochemical properties of the passive films are independent of the composition of the alloys within the passive range. It is presumed that even in the passive region of the potential, below the pitting potential, the chloride ions and water reach the metal surface at the bottom of the defects on the oxide film and react with $\mathrm{Al}^{3+}$ from the metal. However, hydrolysis does not 
produce enough $\mathrm{H}^{+}$for stable pit growth, and a corrosion product (probably aluminum hydroxide) of a different composition than the original oxide film is produced.

In our recent experiments we found localized corrosion in the passive region of the potentials $(-700 \mathrm{mV} \mathrm{SCE})$ after exposure of the a $99.999 \%$ pure $\mathrm{Al}$ specimen in 0.3 wt\% $\mathrm{NaCl}$ for nine hours. A small but continuous increase of anodic current with time (from less than $0.01 \mu \mathrm{A}$ to $0.6 \mu \mathrm{A}$ ) was observed with small oscillations. Shallow $5 \mu$ sized repassivated pits were observed on the aluminum surface. Al of these pits developed laterally but not in depth. It seems that after some time they became inactive. The slow monotonic increase of current indicates that the oxide film (probably that formed on pits) deteriorates continuously with time. A low value of current density within the pits (of the order $1-10 \mathrm{~mA} / \mathrm{cm}^{2}$ ) obtained at the pitting potential was roughly calculated.

It is necessary here to note that a correlation exists between solubility of the oxide and its $\mathrm{pH}_{\mathrm{zch}}$. Solubility of the oxides is dependent on the $\mathrm{PH}_{2 \mathrm{ch}}$ and $\mathrm{pH}$ of the solution. For oxides soluble in acid solutions (line "a" on Figs. 4-6) the higher $\mathrm{pH}_{z \mathrm{ch}}$ the higher is its solubility in 7 to 0 pH's. For oxides stable in acid solutions (line "b" in Figs. 4-6), the lower the $\mathrm{pH}_{2 \mathrm{ch}}$ the higher is the solubility of the oxide in neutral solutions. As $\mathrm{pH}$ changes from 7 to 0 the slope of line " $\mathrm{b}$ " alters from a negative to a positive value. At zero $\mathrm{pH}$, the line "b" merges with line "a."

Because at low/ $\mathrm{pH}$ there is a simple relationship between the $\mathrm{pH}_{2 \mathrm{ch}}$ and the solubility of oxides, it is not surprising that the pitting potential depends also on the $\mathrm{pH}_{2 \mathrm{ch}}$ (Fig. 7). However, the composition of the oxide film formed on the alloys (for example, lack of W 


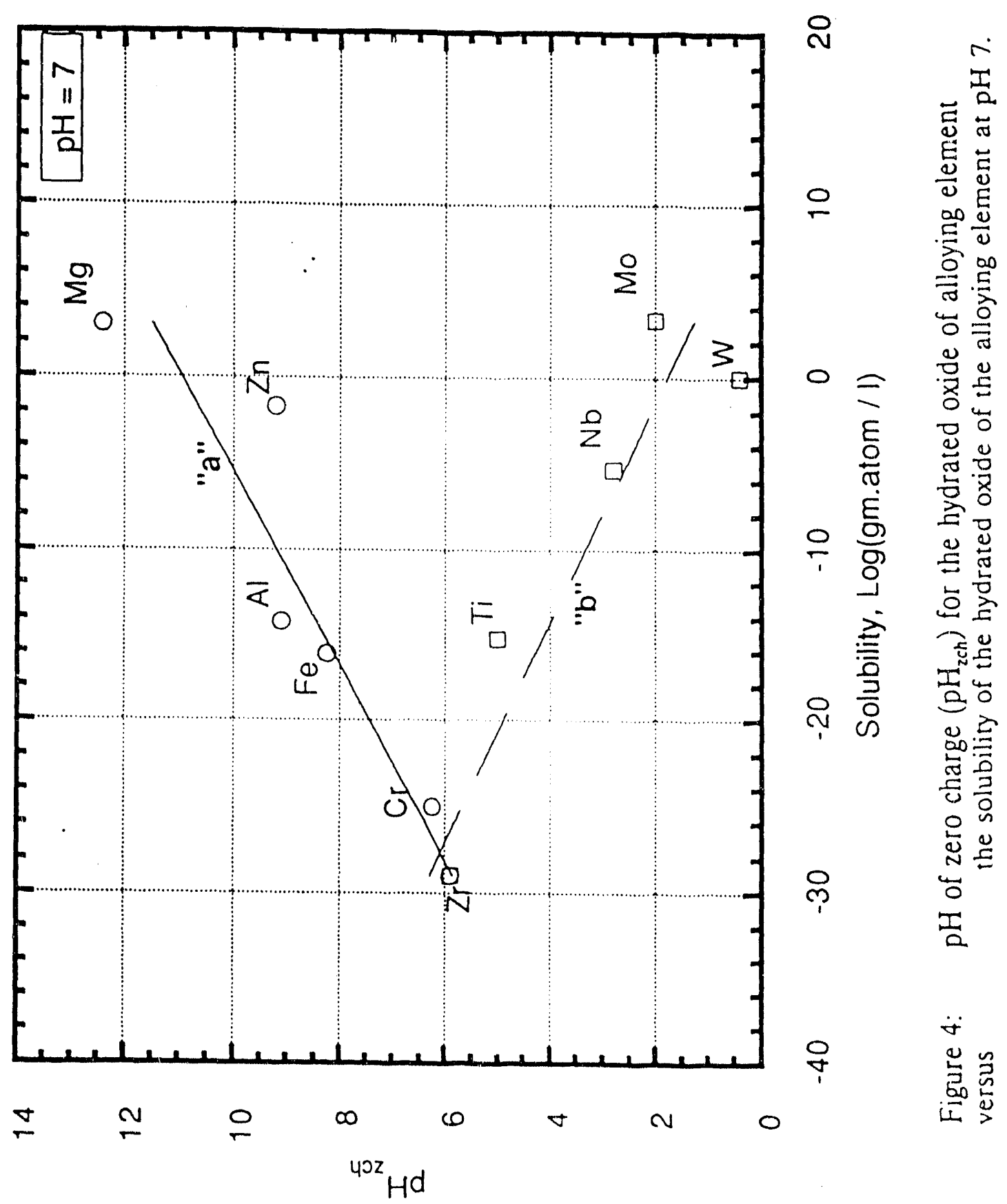









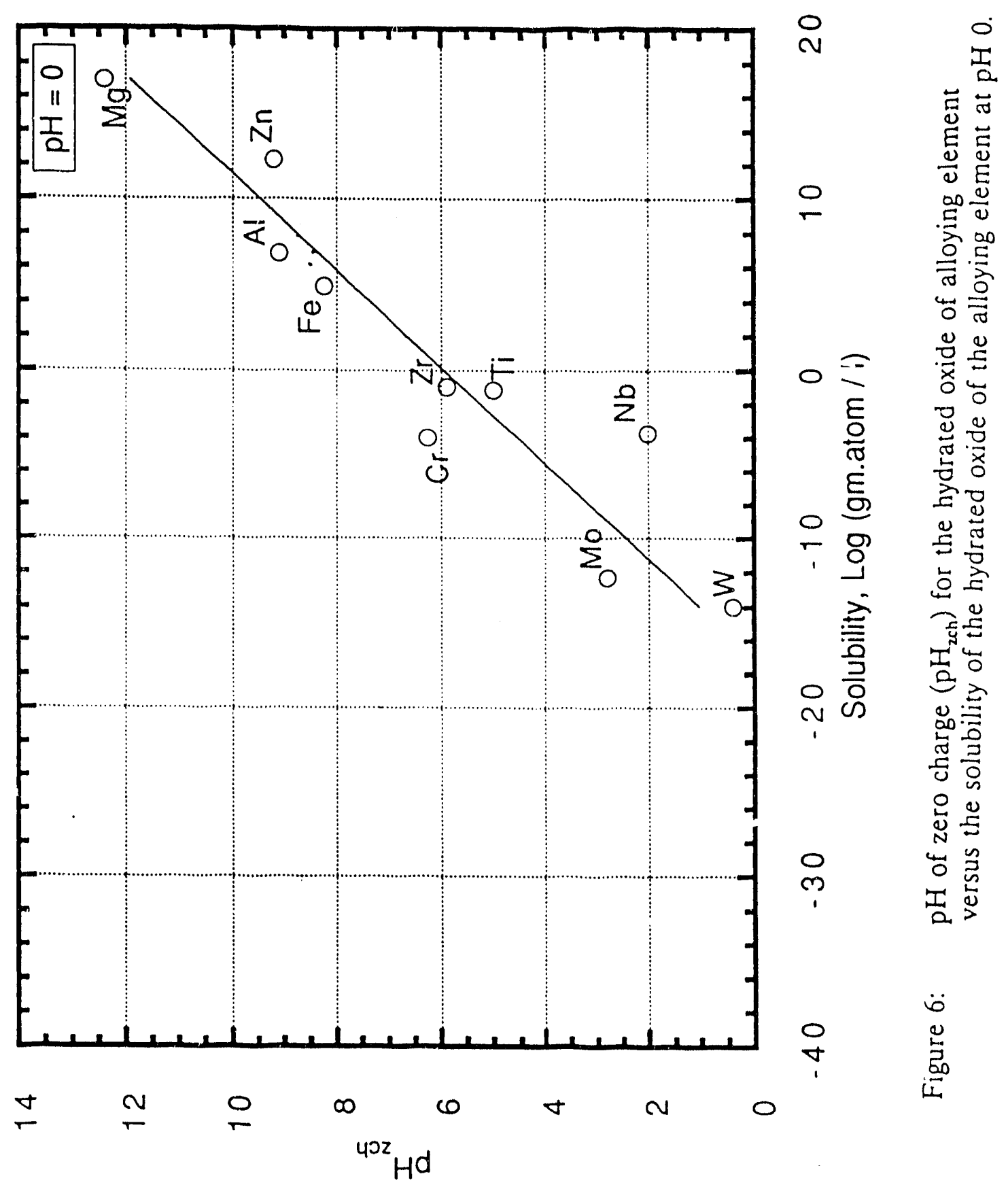




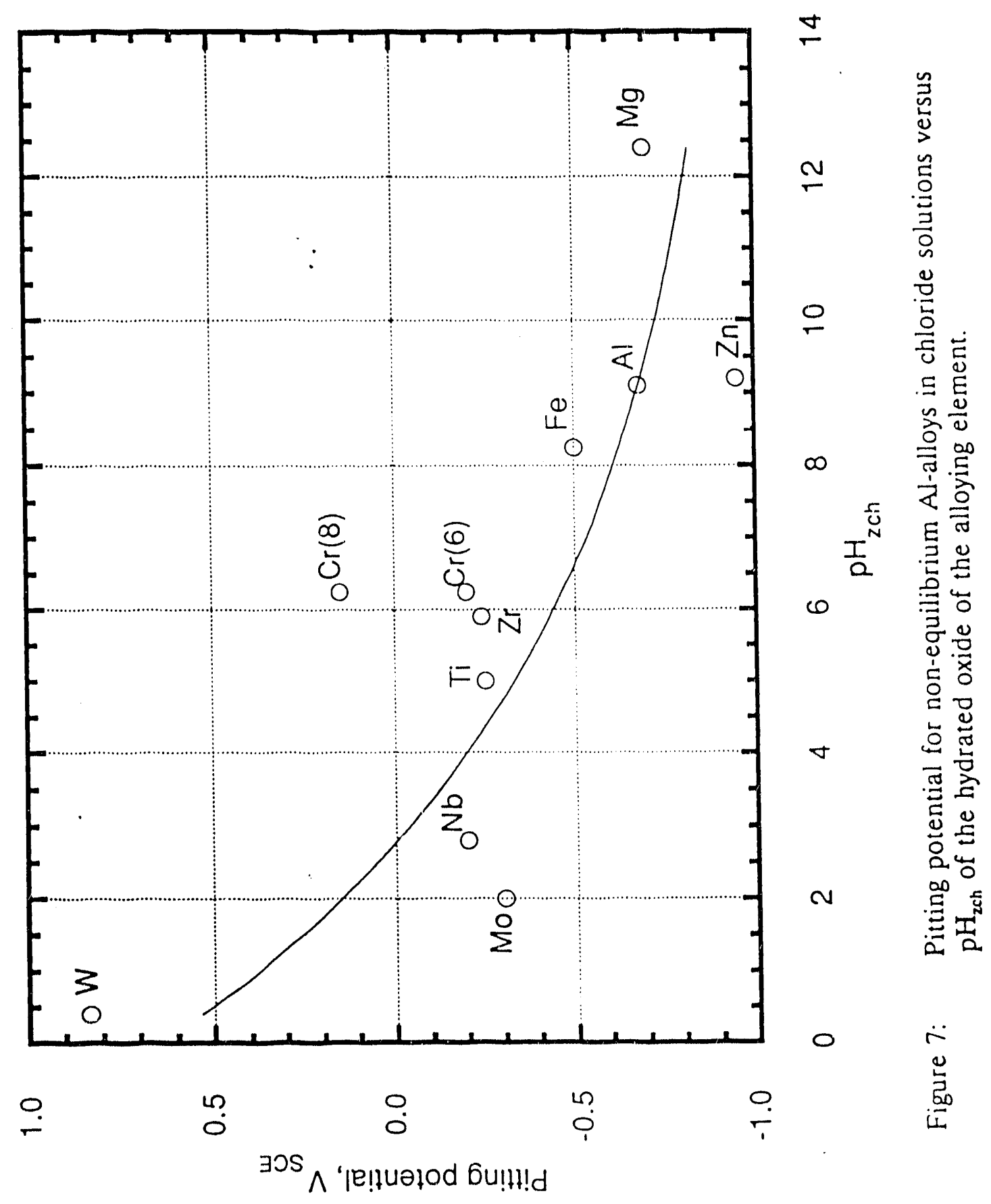


in the oxide film on the Al-W alloy) strongly suggests that solubility of oxides in the pit solution but not adsorption of $\mathrm{Cl}$ - anions on the oxide film determines the pitting potential.

Enrichment of the solute has been observed in the passive film on $\mathrm{Al}-\mathrm{Cr}$ and $\mathrm{Al}-\mathrm{Ta}$ alloy films (3), but not on Al-W alloy films (7). This can be understood by considering the solubilities of the oxidized species of $\mathrm{Cr}, \mathrm{Ta}$ and $\mathrm{W}$ at $\mathrm{pH}$ 7. In neutral solutions, oxidized species of $\mathrm{Cr}$ and $\mathrm{Ta}$ form stable precipitates, thereby incorporating in the passive film, while oxides of $\mathrm{W}$ dissolve in solutions of $\mathrm{pH} 7$ and higher. Mo is not enriched in the passive film at the open circuit potential (18). However, at the applied potential, Mo in the oxide increases initially, but decreases as the applied potential is increased and approaches the pitting potential (4). As the applied potential is increased $\mathrm{Mo}^{6+}$ decreases and the dominant special is $\mathrm{Mo}^{4+}$ in a hydrated state. On the basis of these results, it is concluded that the molybdate in the passive film is probably responsible for the protective properties against pitting and that the pitting potential is a function of the $\mathrm{Mo}^{6+}$ concentration within the pits. However, the structure of the aluminum molybdate is not clear. $\mathrm{MoO}_{2}$ appears to be the most stable oxide in a very narrow range of $\mathrm{pH}(4-6)$ and the potentials. Hence, only in specific conditions is $\mathrm{MoO}_{2}$ responsible for improving the pitting properties. Despite the presence of Mo of different valency, a formation of insoluble aluminum molybdate could be responsible for the resistance of the Al-Mo alloy to pitting and therefore in certain conditions Mo is found in the passive film despite the high solubility of the Mo oxide in neutral solutions. 
Some authors (19-21) believe that a necessary condition for stable pit growth is the presence of salt film at the pit bottom. However, we believe that the presence of a salt film is the result of a high dissolution rate within the pit and the consequent acidification. The chloride salt films (for example, $\mathrm{FeCl}_{2}, \mathrm{NiCl}_{2}$ ) are stable only in highly acidic solutions. Furthermore, from the shape of the pits grown against gravity, toward gravity and sideways on stainless steel specimens, it follows that the salt film present at the bottom of the pits decreases the corrosion rate (1). Another observation that is difficult to explain by the presence of a salt film at the pit bottom is the observation of predominantly crystallographic pits on pure Al. These are often formed close to the pitting potential in dilute chloride solutions and most often on metals that produce open pits (without oxide film covering the pit).

\section{CONCLUSION}

On the basis of information given in this paper, the following mechanism of the pitting of $\mathrm{Al}$-alloys and aluminum is proposed:

It is assumed that the aluminum oxide film is not an effective obstacle for penetration of chloride ions and water to the metal surface. Hence the penetration of chloride ions to the metal is not the rate determining step in pitting corrosion. The rate determining step for stable pit growth is the establishment solution composition within the preexisting defect at the metal/film interface that allows an active dissolution of the metal. This process is controlled by the dissolution rate within the defects and the diffusion (migration) of ionic species into the pit. Metastable pits are formed when the alloy/metal dissolution rate within the pits is too low to sustain a sufficiently low $\mathrm{pH}$. Therefore, repassivation occurs. 
Alloying elements can either cause an increase in $\mathrm{E}_{\mathrm{np}}$ of $\mathrm{Al}$ (when the oxide of an alloying element is less soluble in acid solution than the parent metal, i.e. $\mathrm{Cr}, \mathrm{W}$ oxides) or a decrease in $\mathrm{E}_{\mathrm{np}}$ (when the oxide of an alloying element is more soluble than the parent metal in an acid solution). Hence, the pitting potential is the potential at which the composition of the solution within the pits is such that the passive film within the pits is unstable and a stable dissolution of the alloy occurs. 


\section{REFERENCES}

1. Z. Szklarska-Smialowska, "Pitting Corrosion of Metals," NACE (1986).

2. W. C. Moshier, G. D. Davis, J. S. Ahearn, and H. F. Hough, J. Electrochem. Soc.; 1.33, p. 1063 (1986).

3. G. Davis, W. C. Moshier, T. L. Fritz, and G. O. Cote, J. Electrochem. Soc.; 137. p. 422 (1990).

4. W. C. Moshier, G. D. Davis, and G. O. Cote, J. Electrochem. Soc.; 136, p. 356 (1989).

5. G. D. Davis, V. C. Moshier, T. L. Fritz, G. O. Cote, G. G. Long, and D. R. Black, Annual Report MML TR 89-12 c, Martin Marietta Laboratories (1989).

6. B. A. Shaw, G. D. Davis, T. L. Fritz, and W. C. Moshier; Annual Report MML TR 90-28c, Martin Marietta Laboratories (1990).

7. G. D. Davis, T. L. Fritz, B. J. Rees, B. A. Shaw, and W. C. Moshier, Annual Report MM1 Tr 91-10, Martin Marietta Laboratories (1991).

8. R. Inturi and A. Szklarska-Smialowska, submitted for publication in J. Electrochem. Soc.

9. G. S. Frankel, M. A. Russak, C. V. Jahnes, M. Mirzamaani, and V. Brusic; J. Electrochem. Soc., 136, p. 1243 (1989).

10. P. M. Natishan, E. McCafferty, and G. K. Hubler, J. Electrochem. Soc., 133, p. 1061 (1986). 
11. R. Krishnakumar and Z. Szklarska-Smialowska, "Electrochemical Methods in Corrosion Research," Helsinki (1991).

12. J. R. Galvele, J. Electrochem. Soc., 123, p. 464 (1976).

13. C. B. Carter, A. M. Donald, S. L. Saas; Phil Mag. A 41, p. 467 (1980).

14. CRC Handbook of Chemistry and Physics, ed. by R. C. Weast, CRT Press Inc., p. F187 (1989-90).

15. A. F. Wells, "Structural Inorganic Chemistry," Oxford, Claradan Press, p. 537 (1975).

16. M. F. Abd Rabbo, J. A. Richardson, G. C. Wood, C. K. Jackson, Corr. Sci., 16, p. 677 (1976).

17. B. A. Shaw, G. D. Davis, T. L. Fritz, and K. A. Olver, J. Electrochem Soc., 137, p. 359 (1990).

18. W. C. Moshier, G. D. Davis, J. C. Ahern, and H. F. Hough, J. Electrochem. Soc., 134, p. 2677 (1987).

19. T. R. Beck, "Advances in Localized Corrosion," NACE-9, Editors: H. S. Isaacs, U. Bertocci, J. Kruger, and S. Smialowska, p. 85 (1990).

20. G. S. Frankel, ibid, p. 137.

21. H. Bohni and F. Hunkener, ibid, p. 69.

22. P. M. Natishan, E. McCafferty and G. K. Hubler, J. Electrochem. Soc., 135, p. 321 (1988).

23. M. Faas, D. Itzhak, D. Elieser and F. H. Froes, J. Mater. Sci. Lett., $\underline{6}$, p. 1227 (1987). 
24. G. A. Parks, Chem. Rev. 65 , p. 177 (1965).

25. J. W. Diggle, Oxides and Oxide Films, Ed. J. W. Diggle, 2, p. 297, Marcel Dekker Inc., New York (1973).

26. M. Pourbaix, Atlas of Electrochemical Equilibria in Aqueous Solutions, NACE, CEBELCOR (1974).

27. Journal of Physical and Chemical Reference Data, 11, Suppl. No. 2, "The NBS Tables of Chemical Thermodynamics Properties," published by American Chemical Society (1982). 

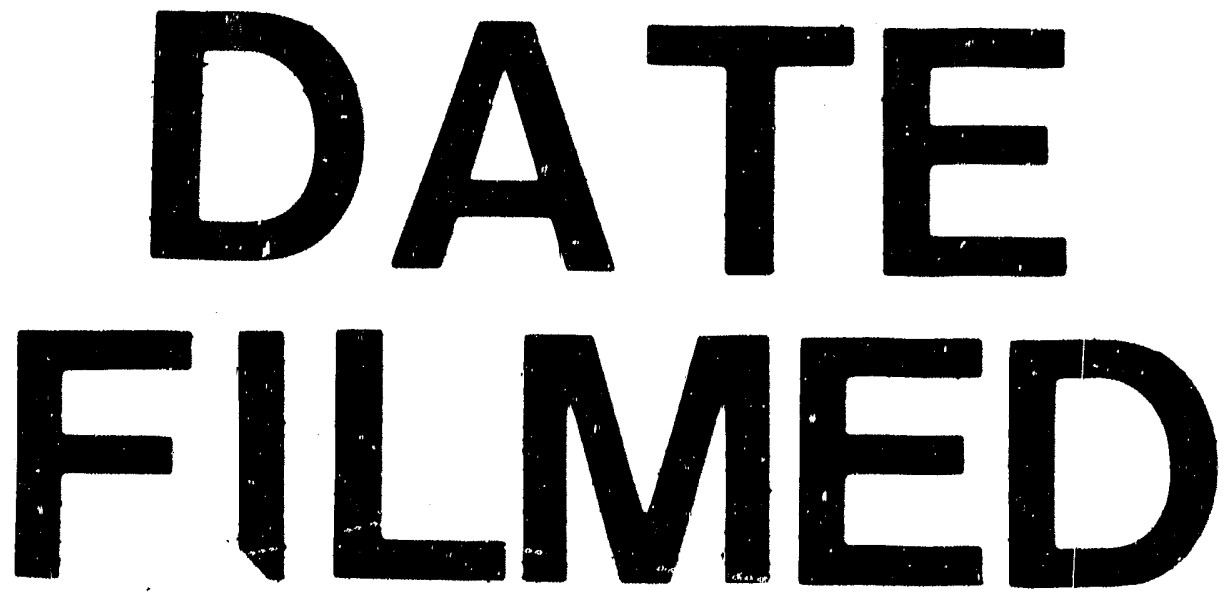

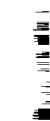

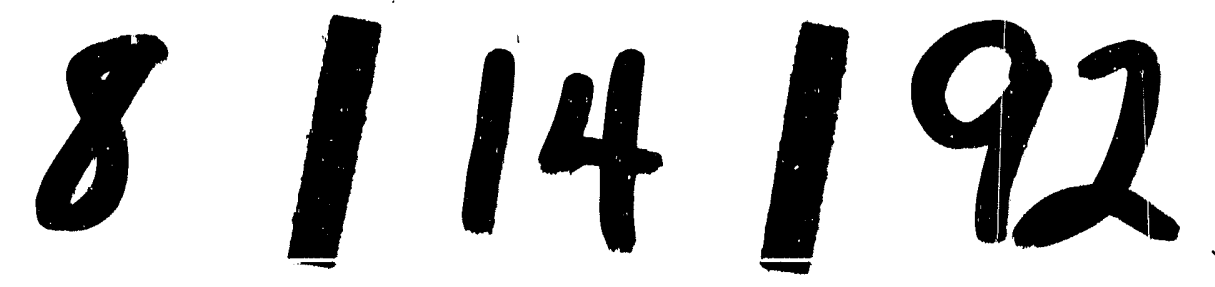






